\title{
ПІДХОДИ ДО РОЗРОБКИ І ПРИЙНЯТТЯ СТРАТЕГІЧНИХ РІШЕНЬ В УМОВАХ НЕВИЗНАЧЕННОСТІ У КОНТЕКСТІ ОНОВЛЕННЯ КОНТЕНТУ ІНФОРМАЦІЙНОГО ЗАБЕЗПЕЧЕННЯ
}

\author{
Барибіна Яніна Олександрівна \\ кандидат економічних наук \\ Вищий навчальний заклад Укоопспілки «Полтавський університет економіки і торгівлі» (м. Полтава, Україна) \\ ORCID ID 0000-0001-8139-9081 \\ barybinaya@ukr.net \\ Шимановська-Діанич Людмила Михайлівна \\ доктор економічних наук \\ Вищий навчальний заклад Укоопспілки «Полтавський університет економіки і торгівлі» (м. Полтава, Україна) \\ ORCID ID: 0000-0001-6499-0953 \\ ludad5846@gmail.com
}

У статті розглянуто особливості формування інформаційного забезпечення щодо розробки стратегічних рішень та вибору стратегії в умовах невизначеності і турбулентності зовнішнього середовища. Запропоновано і розглянуто чотири рівні невизначеності. Надано характеристику основних видів стратегій відповідно до рівнів невизначеності. Встановлено, що сучасна ситуація вимагає переосмислення часового горизонту прийнятття стратегічних рішень, зміни підходів до форммування бізнес-стратегій, які були прийнятними в умовах стабільного зростання ринку, але в умовах турбулентності та невизначеності не працюють, зміни інформаційного контенту прийнятття рішень.

Ключові слова: стратегія, стратегічне рішення, невизначеність, інформаційне забезпечення, стратегічні ризики DOI: https://doi.org/10.32845/bsnau.2019.4.23

Постановка проблеми. Динаміка змін зовнішнього оточення підприємства ускладнюють його стратегічне бачення та створюють додаткові компоненти невизначеності, що загалом набувають форми турбулентності. Стратегічне управління вимагає виваженого прийняття стратегічних рішень, яке повинно враховувати наслідки розроблених планів і надавати можливості щодо розробки тактичних дій виходячи із змін оточення підприємства. За таких умов, перед менеджерами вищої ланки управління постає завдання формування нових підходів щодо прийняття управлінських рішень, зокрема, стратегічних в умовах невизначеності на грунті використання відповідного інфоормаційного забезпечення.

Аналіз останніх джерел і публікацій. Теоретичні та методологічні засади розробки та впровадження механізмів щодо підготовки, прийняття та реалізації управлінських рішень в підприємницьких структурах представлені в працях низки вітчизняних і зарубіжних учених: П. Друкера, Р. Вейль. Р. Саймона, Т. Акоффра, М. Мескона, Т. Клебанової, Р. Фатхутдінова, Л. Гончарової, Г. Осовської, І. Шоробури та інших.

Крім того, у наукових працях багатьох вчених представлено результати дослідження підходів до моделювання процесів прийняття стратегічних рішень в умовах невизначеності та ризику, зокрема, в працях В. Вітлінського, В. Гранатурова, В. Жук, О. Альгіна, Є. Вентцель, Е. Вілкас, С. Наконечного, В. Ковальова, В. Соколова, В. Василенко, Т. Світличної, М. Шигун, С. Хендріксена, І. Балабанова, О. Омарова, С. Клименко, Р. Трухаєв, П. Верченко та інші.

Проте, вкрай фррагментарно представлено результати досліджень питань щодо інформаційного забезпечення процесу прийняття стратегічних рішень, зокрема, в умовах невизначеності та турбулентності зовнішнього середовища, що і зумовило необхідність більш глибокого вивчення даного питання та визначило мету і завдання написання статті.
Мета статті полягає у теоретичному дослідженні процесу прийняття стратегічних рішень в умовах невизначеності та турбулентності зовнішнього середовища і розробці практичних рекомендацій щодо удосконалення практичного інструментарію та інформаційного забезпечення даного процесу..

Викладення основного матеріалу. За прогнозами MBФ, очікується падіння світової економіки на $3 \%$. Україна традиційно є більш вразливою до економічних викликів і ВВП може впасти на 4-8\% у порівнянні 32019 роком. Прогнозоване падіння економіки України $є$ наслідком глобальних економічних викликів: несприятлива ситуація на важливих для України сировинних ринках, закриття товарних ринків для українських експортерів, зміна глобальних виробничих ланцюгів. У підсумку, за прогнозами НБУ, Україна у 2020 році може зіткнутися з падінням експорту (-10\%), імпорту (-14.5\%), розширенням дефіциту бюджету (8\% ВВП) і зростанням рівня безробіття (до 9.5\% ).

Крім того, несприятливою $є$ і ситуація з пандемією, адже економічна рецесія не закінчиться разом 3 тимчасовим припиненням поширенням вірусу. Очікується, що падіння може тривати впродовж року [2]. Ситуація з розповсюдженням пандемії вплинула чи не на кожного суб'єкта господарювання і суттєво змінила часовий горизонт прийняття управлінських рішень, тобто терміни можливого формувати прогнозів щодо вибору типу, виду і напряму виробництва, ціни, заробітної платні та розподілу доходів.

Відтак, поняття стратегічного управління національною економікою, галуззю, підприємством, яке залежить від виважених стратегічних рішень зазнало суттєвих змін і, без перебільшення, можна сказати, що для вчених економістів та управлінців постає завдання пошуку та формування нової управлінської парадигми в умовах турбулентності та невизначеності, яка 6 базувалась на знаннях, інфрормації та комунікації (цифорових комунікаціях). 
Турбулентність або стан невизначеності все частіше проявляються на різних ринках господарювання і причинами виникнення таких станів $є$ розвиток технологій, вибухові інновації, періоди рецесії, які доповнюються новими викликами, зокрема, такими як пандемія або Brexit.

Швидкість реакції бізнесу на зовнішні зміни та якість прийняття стратегічних управлінських рішень впливають на його стійкість та визначають ефективність його функціонування. За цих умов, одним із ключових завдань менеджменту стає адаптація внутрішніх процесів, у тому числі і процесу стратегування діяльності підприємства в умовах невизначеності.

Управлінське рішення - це формалізований на альтернативних засадах метод менеджменту, за допомогою якого керуюча підсистема системи управління підприємства отримує можливість безпосереднього впливу на керовану підсистему [2]. Управлінське рішення формується при виборі альтернативи і є відображенням результатів управлінської діяльності та, певною мірою, ії̈ підсумком. Воно $є$ результатом обдумувань дій і намірів, висновків, міркувань, обговорень тощо, спрямованих на реалізацію цілей управління відповідно до визначення, яке наводиться в «Енциклопедії бізнесмена, економіста, менеджера», а саме: рішення - це висновок за результатами всебічного аналізу розвитку та прогнозування тієї чи іншої ситуації.

Н. Краснокутська зауважує, що управлінське рішення - це результат альтернативної формалізації економічних, технологічних, соціально-психологічних та адміністративних методів менеджменту [4]. Стратегічні рішення є різновидом управлінських рішень і пов'язані з рішеннями, що мають значення для підприємства у цілому: його позиції щодо конкурентів, споживачів, товарів, ринків, макросередовища тощо [5].

Формулювання будь-яких управлінських рішень, зокрема, стратегічних, передбачає використання відповідного інформаційного забезпечення та дієвих аналітичних методів, що дозволяє менеджерам сформувати, з високим рівнем точності, прогноз розвитку галузі та надати необхідну інформацію для прийняття рішень щодо вибору стратегічного напряму розвитку підприємства. Крім того, з позицій системного підходу підприємство $є$ відкритою системою, і управлінські рішення в процесі управління підприємством приймаються на грунті аналізу інформації як об'єкта системи комунікацій, що надходить з внутрішнього та зовнішнього середовища. Враховуючи, що нині підприємства функціонують в мінливих, флуктуаційних умовах, одним з важливих завдань $€$ формування інформаційно-комунікаційних потоків для забезпечення та підвищення ефективності системи управління підприємства в умовах невизначеності та турбулентності зовнішнього середовища та емерджентності економіки [1].

Нині інформаційно-комунікаційні потоки підприємства утворюють організовану систему, яка включає в себе різноманітні технічні, технологічні, віртуальні, інтелектуальні та інші елементи і в роботі з ними задіяна значна кількість працівників [1]. Як зазначає І. Якубенко на підприємстві завжди відбувається обмін інформацією, яка циркулює між різними ланками управління та значно покращує передачу інформації, внаслідок чого підвищується оперативність і адаптивність діяльності підприємства [8].
Поділяючи думку С. Капустник [3], вважаємо, що забезпечення сталого розвитку суб'єктів господарювання безпосередньо пов'язане з розробкою і реалізацією стратегічних управлінських рішень, які характеризуються найбільшим рівнем невизначеності через довгостроковий часовий інтервал і суттєвий вплив наслідків на мету функціонування підприємства. Основними завданнями управління у таких випадках $є$ зменшення імовірності виникнення несприятливих подій та уникнення негативних наслідків і ризиків, зокрема, стратегічних.

Варто зазначити, що науковці В. Черкасова і А. Батенкова, досліджуючи ризик зі стратегічної точки зору, надають змістовне визначення поняттю «стратегічний ризик», що складається з 3-х аспектів [7, с. 67]

1) під стратегічними розуміються ризики, що пов'язані з розробкою неправильних, неадекватних по відношенню до навколишнього середовища планів і моделей поведінки фірми;

2) до стратегічних належать ризики, які пов'язані 3 настанням певних зовнішніх подій, що зроблять неможливим реалізацію обраної стратегії, зумовлюють необхідність її модифрікації або зміни;

3) стратегічні ризики обумовлені помилками в реалізації стратегії навіть за умов, якщо сама стратегія розроблена адекватно, а зовнішні умови є стабільними.

3 цього визначення можна зробити висновок, що на передній план виступає, як раніше було нами зазначено, часовий горизонт прийняття рішень. Сучасна ситуація вимагає переосмислення часового горизонту прийняття стратегічних рішень, зміни підходів до формування бізнес-стратегій, які були прийнятними в умовах стабільного зростання ринку, але в умовах турбулентності та невизначеності не працюють, змін інформаційного контенту прийняття рішень.

Необхідність перегляду горизонту прийняття рішень підкріплюється моделлю А. Савченко та М. Домбровського, яка будується на основі відображення на площині поточного стану підприємства його перспективного стану і відтворює ідеальні уявлення про результати діяльності підприємства, визначені у стратегічному баченні його розвитку [6]

Узагальнюючи думки попередніх авторів, зазначимо, що існує об'єктивна необхідність формування методичного підходу до розробки стратегічних рішень на основі актуальної інформації щодо вибору стратегії підприємства залежно від рівня невизначеності.

Невизначеність, на нашу думку, можна розподілити на 4 рівні:

1 рівень - достатньо точно прогнозоване майбутнє;

2 рівень - альтернативні варіанти майбутнього;

3 рівень - діапазон можливих варіантів майбутнього;

4 рівень - повна невизначеність.

Зупинимось більш детально на визначенні інформації яка необхідна для прийняття рішень щодо вибору стратегії (табл. 1) відповідно до кожного із представлених рівнів невизначеності.

1 рівень - достатньо точно прогнозоване майбутнє.

На цьому рівні залишкова невизначеність не відіграє важливої ролі в ухваленні стратегічних рішень. Менеджерам достатньо розробити один прогноз, який має необхідний ступінь точності і стане базою для корпоративної стратегії. Для його складання використовується стандартний набір ме- 
тодів і інформації: дослідження ринку, аналіз діяльності конкурентів (у першу чергу, структури їх витрат і стану виробничих потужностей), вивчення ланцюга створення вартості, модель п'яти сил Майкла Портера і т.інше. Модель дисконтованого грошового потоку, побудована на основі цього прогнозу, може потім застосовуватися для оцінки альтернативних варіантів можливих стратегій.

2 рівень - альтернативні варіанти майбутнього.

У цьому випадку майбутнє описується, як один з низки відособлених сценаріїв. Аналітичні методи не в змозі виявити, який з них буде втілений в життя, але допомагають визначити ймовірність реалізації того чи іншого варіанту. Найголовніше полягає в тому, що деякі (якщо не всі) елементи стратегії можуть змінитись, якщо результат буде передбачуваним.

У цьому випадку менеджерам необхідно розробити декілька відокремлених сценаріїв, кожен з яких має грунтуватись на тому чи іншому варіанті розвитку подій, пов'язаних 3 ключовими факторами залишкової невизначеності. Для оцінки різних сценаріїв можуть знадобитися різні моделі, які передбачають виконання конкретних завдань:

збір інформації, що сприяє встановленню ступеня ймовірності того чи іншого результату;

вибір відповідних моделей і визначення ймовірностей, при цьому не забороняється використовувати класичну схему аналізу для оцінки ризику і прибутковості, властивих потенційним альтернативних стратегій;

вивчення напрямів за якими піде розвиток галузі в різних випадках, - це дозволить зрозуміти, які ринкові сигнали потрібно відстежувати особливо ретельно.

3 рівень - діапазон можливих варіантів майбутнь020.

На третьому рівні можна виявити діапазон можливих варіантів майбутнього. Він визначається кількома ключовими змінними, однак реальний результат може знаходитися в будь-якій точці цього діапазону. Відокремлених сценаріїв вже не існує, і при цьому, як і в умовах другого рівня, деякі (або всі) елементи стратегії можуть змінитись, за умови, що результат передбачуваний. 3 невизначеністю третього рівня часто зустрічаються компанії, які діють в нових галузях або виходять на нові регіональні ринки.

На третьому рівні невизначеності необхідно: провести аналіз, аналогічний тому, що використовується на другому рівні; виявити низку сценаріїв, що описують альтернативні варіанти майбутнього; відстежити ринкові сигнали, які вказують, в напрямку якого з цих варіантів йде розвиток.

Зауважимо, що розробити чіткі змістовні сценарії на даному рівні невизначеності досить складно. «Природні» дискретні сценарії, які описують дві крайні точки діапазону, створити неважко, але вони не часто застосовуються для вибору конкретного стратегічного рішення. Пошук же відправних точок всередині діапазону, які стануть основою для розгортання альтернативних сценаріїв, - це справжнє мистецтво. Для цього існують загальні правила: nо-перше, слід обмежити число прийнятих до розробки сценаріїв, оскільки складність «жонглювання» більш ніж чотирма-п'ятьма варіантами ускладнює прийняття рішень;

по-друге, необхідно уникати створення зайвих сценаріїв, чий вплив на вибір стратегії не є єдиним у своєму роді; nо-третє, потрібно скласти комплекс сценаріїв, що дає досить ймовірний спектр результатів (тобто не обов'язково прагнути до опису всього діапазону). Така сукупність варіантів дозволить менеджерам оцінити ступінь стійкості діючих стратегій, виявити серед учасників ринку кандидатів в переможці та аутсайдери, визначити ризик реалізації стратегії, націленої на збереження статус-кво.

4 рівень - повна непередбачуваність.

На четвертому рівні невизначеність настільки багатовимірна, що будь-які характеристики відповідного середовища практично не піддаються прогнозуванню. Не можна визначити ні відокремлені сценарії, ні діапазон можливих результатів, ні ті змінні, від яких залежить майбутнє (а іноді навіть виявити їх неможливо). Ситуації невизначеності четвертого рівня виникають не часто і з часом зміщуються в бік однієї з трьох перших, проте, вони існують.

Ситуаційний аналіз на четвертому рівні носить переважно якісний, а не кількісний характер. Разом з тим, необхідно уникати інтуїтивного підходу, який вчені іноді пропонують на противагу раціональному. Навпаки, менеджери повинні систематизувати як відомі їм дані, так і ті, які в принципі можна отримати. Навіть якщо аналіз сукупної інформації не дозволить дати змістовний прогноз можливих (не кажучи вже про ймовірні) варіантів, менеджери все ж складуть загальне уявлення про майбутнє. Вони зможуть виявити певну підмножину змінних, що визначають основний напрям розвитку ринку, а також деякі індикатори, здатні сигналізувати про позитивні або негативні зміни цих змінних.

Керуючись такими індикаторами, менеджери будуть відслідковувати еволюцію ринку та модиффікувати існуючу стратегію в міру надходження додаткової інформації. Крім того, вони зможуть визначити тенденції подальшого розвитку ринку за допомогою таких дій: вивчення історії ринків в умовах невизначеності четвертого рівня, виявлення ключових характеристик переможців і аутсайдерів в подібних ситуаціях, уточнення особливостей стратегій які вони застосовують. В кінцевому результаті, незважаючи на те, що кількісний вимір ризику і прибутковості, які характерні для різних варіантів стратегії, менеджерам не завжди вдається здійснити, вони все ж таки повинні скласти загальне уявлення про те, якій інформації можна довіряти в процесі прийняття стратегічних рішень. Реалістичність цього подання може оцінюватися за допомогою випереджальних ринкових індикаторів і аналізу аналогічних ситуацій.

Більш повна характеристика стратегічних рішень та стратегій відповідно до рівня невизначеності представлена в таблиці 1. 
Таблиия 1

Види стратегій відповідно до рівня невизначеності

\begin{tabular}{|c|c|}
\hline Рівень невизначеності & Пропоновані види стратегій \\
\hline Достатньо точно прогнозоване майбутнє & $\begin{array}{l}\text { адаптивна стратегія - у цьому випадку метою аналізу єскладання прогнозу майбутнього } \\
\text { стану галузі, а стратегічні рішення складаються у виборі ринкових сегментів і засобів } \\
\text { конкурентної боротьби. Якщо аналіз проведений досить ретельно, побудована на його } \\
\text { основі стратегія складається з серії «безпрограшних ходів»; } \\
\text { стратегія фформування - однак вибір даної стратегії пов'язують з певним ризиком. } \\
\text { Компанія, яка взяла на озброєння дану стратегію з метою докорінної зміни усталеної } \\
\text { галузевої структури і поведінки учасників ринку, збільшує тим самим (як для себе, такі для } \\
\text { своїх конкурентів) залишкову невизначеність ринку - в іншому випадку він залишився б } \\
\text { передбачуваним. }\end{array}$ \\
\hline Альтернативні варіанти майбутнього & $\begin{array}{l}\text { стратегія формування - в умовах другого рівня стратегія формування націлена на те, } \\
\text { щоб збільшити ймовірність розвитку галузі за сприятливим для конкретної компанії } \\
\text { сценарієм (використовуючи стратегію формування при наявності першого рівня } \\
\text { невизначеності, компанії намагаються підвищити цей рівень. Навпаки, при існуванні } \\
\text { другого, третього або четвертого рівня невизначеності вони (за допомогою все тієї ж } \\
\text { стратегії) прагнуть знизити його, створивши «порядок замість хаосу».) }\end{array}$ \\
\hline Діапазон можливих варіантів майбутнього & $\begin{array}{l}\text { сттратегія фоормування - за наявності третього рівня невизначеності стратегія } \\
\text { формування видозмінюється. Якщо в умовах другого рівня вона націлена на підвищення } \\
\text { ймовірності втілення конкретного варіанту розвитку подій, то в даному випадку - на } \\
\text { надання ринку загального імпульсу до розвитку, який є вигідним для компанії (оскільки } \\
\text { третій рівень невизначеності дозволяє виявити лише діапазон можливих результатів). }\end{array}$ \\
\hline Повна невизначеність & $\begin{array}{l}\text { стратегія формування - ситуації четвертого рівня (які, відповідно, характеризуються } \\
\text { максимальним ступенем невизначеності) можуть забезпечити компаніям, які обрали дану } \\
\text { стратегію, більш високу прибутковість і менший ризик, ніж ситуації другого і третього рівнів. } \\
\text { Ситуації четвертого рівня невизначеності є, за своєю природою, перехідними. Як правило, } \\
\text { вони виникають в результаті значних технологічних і макроекономічних зрушень або змін } \\
\text { в законодавстві. За цих умов жоден учасник галузевого ринку не знає, якою має бути } \\
\text { оптимальна стратегія. Роль компанії, яка наважилась взяти на озброєння стратегію } \\
\text { формування, полягає в тому, щоб створити загальне уявлення про майбутнє, яке буде } \\
\text { слугувати орієнтиром для інших учасників ринку і сприяти просуванню галузі до більш } \\
\text { стабільної та сприятливої ситуації; } \\
\text { стратедія збереження - по-перше, потрібно прагнути до збільшення «плеча важеля» під } \\
\text { час встановлення співвідношення між власними та залученими фінансовими ресурсами; } \\
\text { по-друге, компанії слід уникати того, щоб через недбалість не опинитися замкненою в } \\
\text { межах однієї стратегічної позиції. }\end{array}$ \\
\hline
\end{tabular}

Висновки. Як бачимо з дослідженого, сучасна ситуація вимагає переосмислення часового горизонту прийняття стратегічних рішень, зміни підходів до формування бізнесстратегій, які були прийнятними в умовах стабільного зростання ринку, але в умовах турбулентності та невизначеності не працюють, змін інформаційного контенту прийняття рішень. Запропоновані нами характеристики рівнів невизначеності при прийнятті рішень щодо вибору стратегії підприємства є актуальними, оскільки прогнози та очікування більшості керівників міжнародного і локального бізнесу нині $€$ невтішними. Вважається, що ми лише на початку великої системної кризи, що ключові ризики, наприклад, екологічні, геополітичні, пандемійні, ще попереду, а це вимагає перегляду підходів щодо отримання інформації та формування ефективних комунікацій для прийняття стратегічних рішень.

Враховуючи, що нині підприємства фрункціонують в мінливих, флуктуаційних умовах, одним з важливих завдань $€$ формування відповідного інформаційного забезпечення як системи управління підприємства в цілому так і процесу прийняття стратегічних рішень в умовах невизначеності та турбулентності зовнішнього середовища та емерджентності економіки

Разом з тим, варто зазначити, що важливим ресурсом в такі турбулентні періоди є топ-команди та ключові працівники i, саме тут, важливим $є$ пошук нових форм взаємодії з персоналом та використання моделей орієнтованих на відповідальну самоорганізацію в досягненні спільних цілей компанії. Крім того, слід розуміти, що глобальні ринки будуть скорочуватися, протекціонізм буде наростати і розумінням цього повинні керуватись топ-менеджери в процесі прийняття стратегічних рішень. Серед найбільш важливих якостей якими повинні володіти бізнес-лідери нового часу є: цілісне і системне бачення світу при прийнятті рішень стратегічного характеру; гнучкість та адаптивність; психологічна стійкість; здатність швидко та ефективно приймати рішення; критичне і творче мислення; вміння надихати в ситуації повного хаосу і непрогнозованості; швидко вчитися та втілювати інновації, що і буде предметом наших подальших досліджень.

\section{Список використаної літератури:}

1. Єршова Н.Ю. Інформаційно-комунікаційне забезпечення прийняття управлінських рішень економічними суб'єктами. Науковий вісник Ужгородського університету. Економіка. 2013. Вип. 39, Ч. 1. С. 96-101.

2. Iнформаційно-аналітичні матеріали URL: https://www.kmu.gov.ua/storage/app/sites/1/18\%20\%20Department/Prezentacii/Programa\%20Ekonomichne\%20stymyluvannia/progr-covid19-analytics.pdf 
3. Капустник С.К. Проблематика ідентифікації ризиків стратегічних рішень підприємств галузі машинобудування/ Науковий вісник УжНУ. СЕРІЯ "ЕКОНОМІКА. 2017. № 49. Том 1. С. 158-167

4. Краснокутська Н.С., Нащекіна О.М., Замула О.В. та ін. Менеджмент : Навчальний посібник. Харків : «Друкарня Мадрид», 2019. $231 \mathrm{C}$.

5. Вороніна А.В., Копил О. В. Прийняття стратегічних рішень в умовах невизначеності та ризику. Молодий вчений. 2016. № 1(1). C35-39

6. Саченко А. О., Домбровський М. 3. , Саченко О. А., Модель розроблення цілей у плануванні стратегічної поведінки підприємства. Східно-Європейський журнал передових технологій. 2013. № 1/10 (61). С. 161-164.

7. Черкасова В. А., Батенкова А. А. Влияние стратегических рисков на финансовые результаты компании. Корпоративные Финансы. 2007. -№ 3. -С. 64-76

8. Якубенко І.М. Інформаційно-комунікаційні потоки в управлінні підприємством. Економіка. Менеджмент. Бізнес. 2018. № 1 (23). C. $90-95$

\section{References:}

1.Yershova, N. YU. (2013). Informatsiyno-komunikatsiyne zabezpechennya pryynyattya upravlins'kykh rishen' ekonomichnymy sub'yektamy [Information and communication support of management decisions by economic entities]. Naukovyy visnyk Uzhhorods'koho universytetu. Ekonomika - Scientific Bulletin of Uzhhorod University. Economy, 39(1), 96-101.

2.Information and analytical materials URL: https://www.kmu.gov.ua/storage/app/sites/1/18\%20-\%20Department/Prezentacii/Programa\%20Ekonomichne\%20stymyluvannia/progr-covid19-analytics.pdf

3.Kapustnyk, S.K. (2017). Problematyka identyfikatsiyi ryzykiv stratehichnykh rishen' pidpryyemstv haluzi mashynobuduvannya [Problems of risk identification of strategic decisions of machine-building enterprises]. Naukovyy visnyk UzhNU. Seriya "Ekonomika" - Scientific herald of Uzhhorod National University. Series "Economics", 49(1), 158-167.

4.Krasnokuts'ka, N. S., Nashchekina, O. M., Zamula, O. V. (2019). Management: A textbook. Kharkiv: Madrid Printing House.

5.Voronina, A.V., Kopyl, O. V. (2016). Pryynyattya stratehichnykh rishen' v umovakh nevyznachenosti ta ryzyku [Making strategic decisions in conditions of uncertainty and risk]. Molodyy vchenyy - $A$ Young Scientist, 1(1), 35-39.

6.Sachenko, A. O., Dombrovs'kyy, M. Z. , Sachenko, O. A. (2013) Model' rozroblennya tsiley u planuvanni stratehichnoyi povedinky pidpryyemstva [Model of development of the purposes in planning of strategic behavior of the enterprise]. SkhidnoYevropeys'kyy zhurnal peredovykh tekhnolohiy - Eastern European Journal of Advanced Technology, 1/10 (61), 161-164.

7.Cherkasova, V. A., Batenkova, A. A. (2007). Vlyyanye stratehycheskykh ryskov na fynansovye rezul'taty kompanyy [The impact of strategic risks on the financial results of the company]. Korporatyvnye Fynansy - Corporate Finance, 3, 64-76.

8.Yakubenko, I.M. (2018). Informatsiyno-komunikatsiyni potoky v upravlinni pidpryyemstvom [Information and communication flows in enterprise management]. Ekonomika. Menedzhment. Biznes - Economy. Management. Business, 1(23), 90-95

Barybina Yanina Oleksandrivna, Dr of Economics, Professor, Poltava University of Economics and Trade (Poltava, Ukraine) Ukraine)

Shymanovska-Dianych Lyudmyla Mykhailivna, PhD in economics, Poltava University of Economics and Trade (Poltava,

Approaches to the development and making of strategic decisions in the conditions of uncertainty in the context of updating the content of information security

The dynamics of changes in the external environment of the enterprise complicate its strategic vision and create additional components of uncertainty, which generally take the form of turbulence. Strategic management requires prudent strategic decisions, which should take into account the consequences of developed plans and provide opportunities for the development of tactical actions based on changes in the environment of the enterprise. The article considers the peculiarities of the formation of information support for the development of strategic decisions and strategy selection in conditions of uncertainty and turbulence of the external environment. Four levels of uncertainty are proposed and considered. Proposed to divide the uncertainty into 4 levels: Level 1 - fairly accurately predicted future; Level 2 - alternatives for the future; Level 3 - a range of possible options for the future; Level 4 - complete uncertainty. It is established that the current situation requires rethinking the time horizon of strategic decision-making, changing approaches to business strategies that were acceptable in conditions of stable market growth, but in conditions of turbulence and uncertainty do not work, changes in information content of decision-making. Our proposed characteristics of the levels of uncertainty in decision-making on the choice of enterprise strategy are relevant, because the forecasts and expectations of most international and local business leaders are now disappointing. The characteristics of the main types of strategies according to the levels of uncertainty are given. It is established that the current situation requires rethinking the time horizon of strategic decision-making, changing approaches to business strategies, which were acceptable in conditions of stable market growth, but in conditions of turbulence and uncertainty do not work, changes in information content of decision-making.

Key words: strategy, strategic decision, uncertainty, information support, strategic risks

Дата надходження до редакції: 27.10.2019 p. 